\title{
ORGANISED CRIME IN PAKISTAN: A CRIMINOLOGICAL STUDY OF MONEY LAUNDERING
}

\author{
Tahseen Ahmed Shaikh* \\ Fateh Muhammad Burfat ${ }^{* *}$
}

\begin{abstract}
Organised crime is chameleonic in nature. It is transnational, dynamic, overlapped criminal activities and pervasive in nature. In the same way, money laundering is the predicate offence and it is naturally linked to other organised crimes. After the cold war, this nexus culminated during the occurrence of 9/11 in particular which was a lethal combination of money laundering $(M L)$ and terrorist financing $(T F)$. This combination is currently being experienced by Pakistan; where various terrorist groups are involved with direct and indirect support of proceeds from drug trafficking, assassination, land grabbing, arms smuggling and various other organised crimes routing through the abusage of financial and non-financial channels and support to terrorism. This has left serious socio-politico and economic consequences in the south Asian region and global as well. The researcher found very limited evidence of money laundering characteristics in the existing research literature on Pakistan. Thus to carry out research work on the subject was need of the hour in Pakistan. This led the researcher to find out root causes and existing weaknesses at the regime's end in countering financial crime and financing of terrorism.
\end{abstract}

Keywords: money laundering, compliance, terrorist financing, corporate governance, organized crime, financial crime, predicate offence

\section{Introduction}

The term 'organised crime' first time used in an annual report of New York Society for Prevention of Crime which was published in the United States of America in 1896. Organised crime was used to crimes like gambling and prostitution. ${ }^{1}$ Till late 80s, initially organised crime was limited only to the USA and later on countries like China, Italy, Colombia and Japan were added in the list. ${ }^{2}$ Organised crime in Pakistan is known to the world as one of the most organised and powerful Mafia in the world. The Pakistani Mafia is spread in many countries and are also politically supported and politicized. Pakistani Mafia groups are mostly ethnically-based and have influence over government. The Pakistani Mafia is involved in drug trafficking, assassination, land grabbing, arms smuggling and various other illegal activities. Pakistan is also known to large drug cartels which export heroin created in Afghanistan. Afghanistan is known to be the largest

\footnotetext{
* Tahseen Ahmed Shaikh, Research Scholar, Department of Criminology, University of Karachi.

${ }^{* *}$ Fateh Muhammad Burfat, Ph.D. Professor, Ex-chairperson, Dept of Criminology, University of Karachi, Vice Chancellor, University of Sindh, Jamshoro

${ }^{1}$ Fijnaut, C. \& Paoli, L. Organised Crime in Europe: Concepts, Patterns and Policies in the European Union and Beyond. (Dodrecht: Springer,2004), 308.

${ }^{2}$ Ibid.,309.
} 
producer of heroin on earth, but due to existing connections to the International waters, most heroin is exported through Pakistan to various regions through different porous sea and land routes.

In the contemporary criminal market; there are number of criminal actors who commit crime in individual capacity; and in such situation the organised criminal groups may not be necessarily present. In fact, the identified criminal markets related to human trafficking, drug trafficking, terrorism and other related crimes are in the North-West and North-East region of the country. These criminal groups require also money laundering channels in the country and commercial banks are the ideal one for them. In such scenario of the criminal organisations in the criminal market of the country require to have huge profits from the available opportunities. These opportunities are inherited by default in the shape of porous borders are here with over-occupied border forces facing terrorism threat, narco-drug cartels, human traffickers and other organised crimes with lack of aerial and land counter-technological measures. Since the most profit involves in criminal organisations in the country, thus the search efforts involve analysis of various factors which favour the organised criminal groups in the criminal markets. The more focus lies on the organised criminal groups or organisations instead of mere crimes which are organised but may not involve groups or organisations. Thus these organised criminal groups or organisations divert their ill-gotten money into legitimate businesses and the country's economy which leads to vulnerability of legitimate economy of the country.

By reviewing international literature and data on Pakistan, the researcher found that no specific money laundering activities were addressed on the basis of criminological aspects. This may involve how the organised groups commit criminal activities of money laundering in Pakistan and involvement of transnational methodologies. Every research work has inherited shortcomings along with positive aspects. The researcher found very limited evidence of money laundering characteristics and evidence in the existing research literature on Pakistan. Thus to carry out research work on the subject was need of the hour in Pakistan. This helped the researcher to find out root causes and existing weaknesses at the regime's end in countering financial crime and financing of terrorism. Since country like Pakistan has fragile financial institutions. This vulnerability of weak institutions sways the criminal networks to launder their illicit proceeds. These root causes were seen through the prism of theories presented by various sociologists and criminologists.

This research also analysed the abusage of financial and non-financial institutions for facilitating financial crime and financing of terrorism. The method of case studies was not ignored and helped to review various typologies and methodologies involved in commission of different organised crimes. During this analysis, the researcher finds weak anti financial crime and financing of terrorism regime in Pakistan. This is evidenced from the contemporary measures that have been yet taken. The inherited flaws in legislature also cause confusion in the enforcement efforts by the enforcement agencies. It cannot be denied that Pakistan is combating a qualitative new phenomenon with obsolete tools, weak enforced laws, corrupt bureaucratic hierarchy and unworkable strategies. The fundamental changes have given the criminal organised networks a new intensity, since the last decade, which are likely to persist. Criminal networks exploit pervasiveness of 
technological advancement more efficiently than the government. Government should recognise that sovereignty is daily compromised at the hands of stateless organised criminal networks. These are involved in money laundering; terrorist financing and other related organised crimes.

Money laundering and terrorist financing are transnational organised crimes. Information revolution has shrinked geographic distances among nation-states. At the global level; the absence or weak compliance regime, less centralization and poor budget allocation have aggravated anti financial crime and terrorist financing compliance regime's work. Thus it requires to analyse working and reviewing various measures taken by the regional and global regime in countering financial crime. These global and regional regimes involve international and regional bodies like- FATF, APG, Wolfsberg Group of Banks, UNODC, Basel Committee Banking Supervision; European Union and many other bodies.

Financial crime and terrorist financing have serious socio-politico and economic consequences. Weak money laundering regime is the main cause of fragile financial system and reputational risk. This is not limited to the country, but has broader impacts on global economy. Strong anti-financial crime and financing of terrorism regime is need of the hour. Strategy of Pakistan has regional and international impact, since Pakistan is strategically located in the Asia region. Active presence of Al-Qaida, other non-state actors, porous borders with Afghanistan, cash based and undocumented economy are serious vulnerabilities and need immediate check over these. All countries in the region require to beef-up efforts against financial crime and financing of terrorism at local, regional and international level. Pakistan has showed its international commitment to the global stakeholders for adopting multi-prong strategies. But there is a long way to go in countering financial crime and financing of terrorism.

In sociological and criminological sciences, the theoretical framework has a great significance. It provides an opportunity to the researcher to analyse and draw inferences through the collected literature and data in the light of philosophy and theories of various theorists. Merton defined Sociological theory as "logically interconnected sets of propositions from which empirical uniformities can be derived". In fact theory is an educational device which helps to study the actual phenomenon. This also applies to the concept of organised crime; that can be considered by selecting some related models or theories of some experts of the subject. ${ }^{3}$ Because of implicit ideologies, term of organised crime is understood in diverse contexts. ${ }^{4}$ The theories on organised crime provide limited understanding of it, since unclear concept of organised crime. ${ }^{5}$ Cesoni M.L. observed that the vague concept of organised crime is the outcome of offering all-embracing definition

\footnotetext{
${ }^{3}$ Gottschalk, Petter, Policing Organised Crime: Intelligence Strategy Implementation. (Boca Raton: CRC Press, 2010), 35

${ }^{4}$ Duyne, P. C. Van, Organised Crime in Europe. (New York: Nova Science Publishers, 1995), 137.

${ }^{5}$ Kelly, Robert J., Organised Crime: A Study in the Production of Knowledge by Law Enforcement Specialists. (New York: The City University of New York, 1978),43.
} 
of organised crime. ${ }^{6}$ Therefore it is an effort to understand the concept of organised crime which led to different theories and concepts by the many scholars. ${ }^{7}$ Due to chameleonic nature of crime, Buscaglia, Gonzalez-Reiz and Ratcliff submit that to make a law or definition on organised crime, the only way is to import from outside and adjust it according to the cultural context of one's own country. ${ }^{8}$ Therefore, Obokata concedes that there are many ways to describe 'organised crime' as it changes into various forms when in practice. ${ }^{9}$

The researcher included various sociological and criminological theories for explaining research issues. Despite the fact, the selected subject of the research had limited theories in sociology and criminology. But the researcher tried his level best to analyse criminologically, the spread of organised crime particularly with reference to money laundering in the country. These theories include anomie theory, theory of motivation and opportunity, theory of differential association, theories of cultural deviance, theories of social disorganisation, rational choice theory, social learning theory, differential reenforcement theory, theory of basic needs and modeling and control theories. These theories involved various behaviours, attitudes, associations, conflict of ideas and norms. However, the researcher further opted Contingency Model which described the involvement of participants and non- participants related to organised crime ${ }^{10}{ }^{1}$ Under this model, seven theories were differentiated according to various concepts of organised crime. Counter role of stake holders in the country particularly and globally in general against money laundering was also reviewed under the contemporary counter laws and measures in Pakistan. The contemporary socio-economic and psychological tendencies with cultural influence related to organised crime with reference to money laundering were also reviewed.

Any current research work provides basis and directions for future work. But it is supported by the previous literature and studies which are available on the related subject of the research. Infact, in each era, the social scientists and theorists observe the earlier generations. This helps them to produce their new studies more result-oriented, objective and innovative. This also leads to review the generalizations formed from the previous studies which is very significant in social studies. These reviews of past studies and literature contribute towards welfare and well-being of people in general. It introduces new concepts and replacing the earlier deficiencies with solutions for the wellbeing of people.

The researcher believes that in most of the cases in Pakistan related to formation of public policies; these are less dependent on the contemporary analysis, researches and

${ }^{6}$ Cesoni, Maria Luisa, Mafia-Type Organizations: The Restoration of Rights as a Preventive Policy in Viano Emilio C Viano Emilio C (ed) Global Organised Crime and International Security. (Aldershot:Ashgate, 1999), 157- 171.

${ }^{7}$ Von Lampe, Klaus, Organised Crime in Europe. in Reichel Philip (ed) Handbook of Transnational Crime and Justice (Thousand Oaks: Sage Publications, 2005), 403-424.

${ }^{8}$ Buscaglia, Edgardo, Samuel, Gonzalez-Reiz, and Ratcliff, William, Undermining the Foundations of Organised Crime and Public Sector Corruption: An Essay on Best International Practices. (Stanford: Hoover Institution on War, 2005), 27.

${ }^{9}$ Obokata, Tom, Transnational Organised Crime in International Law. (Oxford: Hart Publishing, 2010), 119.

${ }^{10}$ Layman, M. D. \& Potter, G. V. Organised Crime. (Skopje: Magor, 2009), 213-221. 
surveys. The public policies are dependent on fragile visions and understanding of bureaucrats and political elites; and these are formulated for their vested political and economic interests instead of well-being of people. It is therefore, the researcher believed that before reaching to any insight and conclusion; the literature review and past studies on organised crime needed to review initially.

Since money laundering is multi-faceted organised crime and linked to other organised crimes in one way or the other; whether, there is terrorist financing, human trafficking, narco-drug trafficking, corruption and many others. So the literature related to interlinked organised crimes was preferred by the researcher to have profound review of those issues which was helpful to the research in hand. Besides that; the researcher found those studies to have critical review of methodologies in vogue at the country level related to organised crimes. The effectiveness of contemporary laws and measures needed to be reviewed at the country level in particular and global measures in general. Those provided an opportunity to the researcher to forward analysis and suggest measures for effective working against financial crime and financing of terrorism under strict enforcement, regulation and anti-money laundering governance regime in the country. This humble work relied on the past studies and their reviews which cannot be ignored in any ways.

\section{Objectives of Study}

The present research aims to perform the review of various types of organised crime, particularly with reference to financial crime and financing of terrorism in Pakistan. It would analyse various mythologies involved in commission of crime. The study would trace the legal and regulatory preventive measures and finding lapses in counter strategies against financial crime and financing of terrorism in the country. Appended objectives are set as:

1. To analyse the nature of organised crime in general and techniques of money laundering particularly in Pakistan.

2. To examine government's strategy to counter money laundering and terrorist financing.

3. To synchronise counter measures by Pakistan involving policies, statutes and other agents with global money laundering and terrorist financing regime.

\section{Methodology}

Qualitative method was applied in collecting, collating, reviewing and interpreting the problem from sociological, criminological and psychological aspects. Different methods of data collection were adopted under qualitative research method. The aim of the study was to collect evidence, seek answers to research questions and use systematically predefined set of procedures. Furthermore, the method supported to collect findings that were not determined before. Those findings could be applicable beyond the immediate boundaries of the study. Snow ball technique was adopted by the researcher which proved very helpful in collection of qualitative information from the respondents. 
The data pertained to law enforcement, regulatory, judicial, legislative and other various aspects of society. Qualitative method was elaborated and it encompassed various case studies with different modus of operandi. Sutherland states "the most important thing to know about crime is the mechanism by which it is produced, and such knowledge can be secured better by individual case studies". ${ }^{11}$ The cases are units of analysis and become the basis for purposeful sampling in qualitative inquiry. ${ }^{12}$ Studies focusing on society and culture in a group, a programme, department or an organization typically espouse some forms of case study as strategy. ${ }^{13}$ Through the method of data collection, the case study provides an opportunity to collect date comprehensively in a systematic way with profound information in each case study.

The method also included different interviewees as respondents. The specified criteria of Key Informants Interviews (KIIs) was adopted while selecting the procedure of interviewees. The collected information could be primary and secondary as well as it assisted to seek answers and findings with evidence to the unresolved questions from various respondents who were related to the issues of financial crime and financing of terrorism with other organised crimes particularly in Pakistan and transnational in general. Patton in his work Qualitative evaluation and research methods (2nd ed.) mentions that through the purposive sample, the researcher identifies some respondents who could provide significant data on the research subject. However, for this aim, purposive sampling procedure was implied. The profile of the respondents viewed and ensured that they had linkages with enforcement agencies, judicial system, legislature, banks, regulators and other related fields. The researcher preferred to refer and relate information in the research which could not create controversies out of any biased information and had no logical reasons.

Karachi was primarily selected as the universe of the study. Since Karachi is considered as hub of commercial, financial and economic activities and majority of head offices of various departments are located in the city.

\section{Findings}

According to section 2(m) of the Anti-Money Laundering Act 2010, some professionals and non-financial businesses were covered. But professionals like bureaucrats, politicians and armed forces were neither named nor discussed. The Act has not an exhaustive anti money laundering legislation in the legal systems to cover as many practical scenarios. But on the other hand, the Act is very limited in its scope and parameters. The term "associates" limits the scope of criminalization in some way. It is not clear whether the term "associates" in S. 3d of the Act involves additional element. But the designated categories of offences as proscribed by the Financial Action Task Force are not incorporated as a predicate offence under AMLA 2010. To prove the offence of money

\footnotetext{
${ }^{11}$ Sutherland, Edwin H., The Professional Thief: By A Professional Thief. (Chicago: The University of Chicago Press, 1937),86.

${ }^{12}$ Patton, M., Qualitative Evaluation and Research Methods. (Beverly Hills CA: Sage, 1990), 169-186.

${ }^{13}$ Van Vliet, Gretchen L. A Partnership for Global Health: Expanding Curriculum and Research in Global

Health (University of North Carolina: Chapel Hill, 2006), 10-11.
} 
laundering involving the intent and knowledge, is not in line with the standards set out in the Vienna and Palermo Conventions.

Under S. 37 of AML Act 2010; it is found that the scope of corporate criminal liability is limited in scope. Corporate criminal liability under Pakistani law requires strict liability of the responsible natural persons who act on its behalf. Thus practice of lack of prosecution under this provision by the investigative agencies is due to the narrow scope of the offences by companies. AML Act 2010 has more than one procedure of forfeiture, each of which is complex, particularly with reference to S.2 (q), 4,9 \& 17 (5). But the financial sanctions or fine under S.4 do not put the serious deterrence against the offence of money laundering. Thus the maximum penalty of 1 million rupees is insufficient to those involved in money laundering particularly in the case of criminal liability of corporations.

Under the Anti-Terrorism Act 1997, freezing is done in Pakistan in pursuance to UNSCR 1373. Prohibition has very limited scope and it is limited to "organizations"; and freezing is restricted to the seizing of the offices, bank accounts and confiscation of cash found at the possession. It doesn't consider in broader scope of freezing when it is comparatively reviewed with UNSCR 1373. Mens-rea is requisite in each case, which is termed in knowledge or intention related to "purpose of terrorism". The prohibition procedure under the UN ACT may enable Pakistan to enforce freezing of the assets of entities enlisted by another State and entity possessing a "distinctive name". In the light of this requirement, prohibition is not clearly related to Anti-Terrorism (Amendment) Ordinance, 2001 which is "domestically-focused". It may restrict Pakistan's influence to use the prohibition procedure this way until the concerned entity is also found a domestic threat to Pakistan. Thus the Act doesn't intimidate international terrorist organizations.

The act of "enters into or becomes concerned in an arrangement" under S 11J of AntiTerrorism Act seems to be broader. However, it will be subject to judiciary's interpretation and may not be clear as the term "collection." This confusion could only be decided through the court verdicts. Thus leaving some acts of collection outside the scope of the criminalization except in relation to proscribed organizations; the researcher considers that the gap is unlikely going to be very small.

According to Anti-Terrorism Act 1997 which was later amended as the Anti-Terrorism (Amendment) Ordinance, 2001 doesn't completely encompass the predicate offences. The question still arises, if definition of terrorism under the Anti-Terrorism (Amendment) Ordinance, 2001 applies to all acts proscribed under the terrorism Conventions as covered under the Special Recommendations of FATF. Section 11 of the ATA prohibits various acts related to financing. The offences also certainly linked to the financing of "proscribed organizations." The ATA offences do not however encompass financial support to terrorist organizations which are not proscribed organizations. "Terrorism" is defined but it doesn't include financing of terrorism, except for a proscribed organizations. Unless the proscribed entity is involved, instrumentalities of financing of terrorism could not be confiscated. The restricted freezing powers only encompass assets of "proscribed organizations", which include "its" offices and accounts. It is unclear 
about freezing of offices and accounts of third parties which are supportive to proscribed organizations.

When researcher reviewed the performance of the regulatory regime, some of the avenues were found missing or weak compliance at the end of various bodies. Pakistan established Financial Monitoring Unit under the AML ACT 2010 for the sake of analyzing and disseminating Suspicious Transaction Reports-STRs. However, its operational independence is limited, since it is not adequately guaranteed of its staffing, budgeting and sharing of information at the international level. Access to information of FMU is very limited and absence of systematic approach towards the collection of information hampers the effectiveness of information required after receiving of STRs at the FMU end. Suspicious information is forwarded by financial institutions through Cash Transaction Report-CTR and Suspicious Transaction Report-STR to FMU. There is not any clear definition of suspicion found in the cotemporary laws. Suspicion could be for the one and not for the other. Thus, the suspicion term is vague. The definition of suspicious transaction is subjective in nature in the AML Act 2010 as it does not hold cases of an individual "suspects" or "has reason to suspect" that funds are outcome of criminal activism. The Act also does not entail any specific requirement to report transactions in relation to financing of terrorism. Moreover, the legal framework is further complicated; since AML Act doesn't hold wide range of counter measures beyond requirements of reporting the suspicious transactions. Infact the provided sections- 44 and 6 have limited scope.

The operation of FMU is not so independent as it was envisaged under S.6 (2) of AML Act 2010. But on the other hand, in S 5(4) AML Act 2010 puts some checks on FMU by giving authority of supervision and control to the General Committee over it. But in practice, the General Committee has delegated such powers to the Governor of State Bank of Pakistan. Thus here it arises two issues: (i) ineffective autonomy of the FMU due to the control of Governor (ii) not clear whether AML Act permits or supports such powers to be taken from the GC. The factor of oversight the working of FMU cannot be denied. Since it is the national regulatory body and it needs some checks over its working. But it should not be at the cost of its autonomy. FMU's sharing of information according to the AML Act also falls under the Egmont Principles of Exchange of Information among FIUs. This is also specified in the S. 6 (4)(e) AML Act for sharing of information with outside counterparts. But on the other hand, S.26 AML Act gives a broader mandate and involves Federal Government to form an agreement for foreign cooperation. Thus, S.26 overrides S. 6 (4)(e) in respect of cooperation. So as a matter of practice, all the departments/ agencies before come into agreement have to rout through the Foreign Ministry. So it is negation of the earlier provision of spontaneous cooperation to or from FMU.

There is an excessive focus on the identification tools related to NADRA/NARA. State Bank of Pakistan has been assertive on these requirements, both through stringent compliance and imposition of fines. Financial institutions in Pakistan are still in short of resources to implement robust IT systems for effective on going monitoring. Despite the fact improvement has been made, in comparison to situation as it was five years before as 
it had been less systematic and in-depth. Though STR reporting to FMU has increased, but there is still a long journey to come by.

There is no one formal platform, where various agencies meet together and chalk out strategy for effective implementation of AML and CFT measures in Pakistan. This is a serious impediment in the systematic improvement and implementation of coordinated policies. However, interagency coordination (provincial police, FIA, IB, ISI) is limited in scope by involving only combating terrorism issues in Pakistan. It does not involve financing of terrorism issues, FMU and other stakeholders. Money Laundering (ML) and Terrorism Financing (TF) are criminalised by Pakistan. The law enforcement agencies find it difficult to collect evidence in ML for getting conviction in the predicate offence; which is prerequisite. However, the range of predicate offences in contemporary laws of Pakistan is limited. The term 'investigating agency' in AML Act is limited to NAB, ANF, and the FIA under S. 2 (j). Thus, the investigation of information received through financial institutions is very limited to only some federal enforcement agencies. It does not consider provincially controlled police department, Federal customs and tax authorities. Involvement of Police at the provincial level and multi federal agencies in curbing ML, FT and predicate offences has resulted in fragmentation and complexity of work. There is good understanding of the terrorism risk. But no adequate mapping of the risk; methods of financing of terrorism among law enforcement agencies and the lack of awareness of the usage of tools to pursue the trail of finance as means of preventing terrorism.

The criminal justice system's traditional goal is to dispense justice and punish offenders for their improper conduct. Some failures of justice are not accidental or case-specific, but result from the non-proper application of a legal rule. There have been no impressive convictions under Anti Money Laundering and Anti-Terrorism Act, which could justify effectiveness of forfeiture regime. As noted, non-clarity in its forfeiture provisions undermine effectiveness forfeiture regime. AML Act holds certain procedural ambiguities that tend to impact the effectiveness of forfeiture regime.

The US Department of State Report states that the current measures to counter the routing of illicit proceeds through welfare or charitable organizations are limited in scope. There is little trace on suspected individual associates linked with charities in question. Thus these sometime emerge as non-state actors and allowing them to operate freely under alternate names. The judicial system has also not been so effective which could affirm Pakistan's international obligations and maintain closure of UN's proscribed charitable organizations. Reportedly, frequent cash couriers are the main channel of financing terrorist activities.

In Palermo Convention, Stefano Betti supports that the Palermo Convention needs a profound monitoring system and relying on normative criteria alone is not enough. Giuseppe Di Gennaro writes, in his article "Strengthening the International Legal System in Order to Combat Transnational Crime", that the international community has not made commendable efforts in fighting against organised crime. Rather he deplores that the conditions have deteriorated. However he concedes that if no earlier efforts had been 
taken by the Palermo Convention, there would have been more deterioration globally. ${ }^{14}$ He further reviewed and shared his findings in Palermo Convention in a UN report titled; "A more secure world: our shared responsibility Report of the High-level Panel on Threats" It outlines serious threats the international community is facing from Transnational Organised Crime (TNOC). The report has been critical that states and international organisations have responded too slowly against the threat of organised crime and corruption. This is testified from the collected information that there was found weak cooperation among the states, insufficient coordination among international anti organised crime regimes and non-satisfied compliance measures taken by many states. These can be evidenced from the increasing demand of narco- drugs and its availability in the global markets. This is also the same for increasing corruption at different states and poor remedies available to curb these.

The principal problem with this new networked form of global governance of AML \& CFT Regime is that it lacks vital characteristics of democratic governance. First, it lacks accountability. For instance, representatives in FATF, unlike ambassadors to the U.N., are not directly accountable to their states. Second, it underlines current power asymmetries in the international system. Formed by the G-7/G-8 countries, FATF is dominated by the same major powers who dominate the U.N. and other institutions of global governance. Wilke notes that these states control much of the world's stored data about corruption due to the sensitive nature of such information. ${ }^{15}$ Third, storing of information by the major powers and developed countries puts developing countries at a huge disadvantage. Information on politicians and other leading actors in poor countries makes them vulnerable to political pressure. Since developing nations often rely on advanced industrial countries for aid and technical assistance, they also depend on richer countries for data storage. Fourth, as noted before, the adhoc organisations of global governance are not fully transparent or accountable. Thus manifest a clear democratic deficit. They are thus plagued by questions of legitimacy. As Slaughter notes, networks only possess legitimacy if all states join, and the most networked states tend to be most powerful. ${ }^{16}$

One positive step that has allowed the inclusion of more countries is the recent G-20 Summit process. This has included several developing countries, which formerly were not involved in major international summit, including countries that ostensibly represent whole regions of the developing world. Their inclusion is critical to the future success of any financial regime. Moreover, the creation of FATF Style Regional Bodies-FSRBs may well boost participation of countries from various regions.

\footnotetext{
${ }^{14}$ Betti, Stefano, The European Union and the United Nations Convention Against Transnational Organised Crime in European Parliament Working Paper, Civil Liberties Series LIBE 116 EN (Brussels: European Parliament, 2001), 118.

${ }^{15}$ Wilke, Marie, Emerging Informal Network Structures in Global Governance. (Nordic Journal of International Law. Vol. 77, No. 4 (2008), 523.

${ }^{16}$ Slaughter, Anne-Marie, A New World Order. (New Jersey: Princeton University Press, 2004), 53.
} 


\section{Discussion}

After reviewing the commission of financial crime and financing of terrorism, it is found that Rational Choice theory is closer to these crimes. The offender is motivated by various gains after laundering illicit generated proceeds through various layering tactics of concealment. So that it should look legal in the country and may contribute in terrorist financing through legal means with malafide purpose of terrorism. Another factor which motivates criminals related to the commission of crime is the weak enforcement or operations and loopholes in the mapping of anti-financial crime and financing of terrorism in the legal system. Criminals also assess less risk of punishment and other weak enforcement in tracing and prosecution of financial crime and financing of terrorism crimes. This transpires the theory of Deterrence as well; which says that people choose to obey or violate the law after having calculated gains and pains of their actions. Here after calculating the risks of punishment, the organised criminals feel little reluctance to commit these organised crimes and which are soaring with the passage of time in the country.

Thus the concept of Special Deterrence Theory doesn't look to be workable; where rigorous punishments are already incorporated in the AML Act 2010 and Anti-Terrorism Act about the commission of these organised crimes. But due to weak prosecution, lacunae in investigations and non-impressive enforcement lead to conviction ratio miserably very low against the commission of financial crime and financing of terrorism. Conviction can be inflicted by the legal system; if effective investigation and enforcement measures are taken. AML Act 2010 doesn't comprehensively commensurate with the significant risks that the country is facing. Lack of understanding amongst investigating agencies of the scope and possible use of financial crime; lack of capacity to trace the trail of financial support at an early stage of the investigation; and extreme difficulty in proving the money trail from criminal proceeds due to high standard of proof as required by the courts. These are some of the impediments in the way of effective implementation of AML Act 2010.

When FMU shares information with any law enforcement agency according to law, in some cases it is not clear to FMU about the involvement of the customer in the commission of any predicate offence or multiple crimes. There is no framework about the dissemination of information that on what basis any specified enforcement agency is selected for investigation of suspicion as raised by the financial institution. Keeping in mind nature of suspicion of transactions raised by the financial institutions, the received information needs to be immediately disseminated to the concerned law enforcement agency. Due to absence of any period mentioned of the dissemination at the FMU end; there is more vulnerability of commission of crime and missing of culprits, till the responsible agency comes into action.

One of the most important impediments of the AML/CFT strategy is to engage FIUs in international coordination. The major barrier is to remove legal obstacles in the information sharing, improving systems to impart the confidentiality of exchanged 
information. ${ }^{17}$ Levi and Gilmore believe that currently the difference in approach and procedure among various regions is major cause of failure in information exchange. Moreover, similar differences between regulators result in obstruction for satisfactory, effective and timely information exchange. They pointed out that it was never clear whether monitoring controls and confiscation form sufficient constraints as a part of success. It is not clear, how it would be pointed out if and when 'success' was believed to require a major global network of acceptable legislation and coordinated legal support, both for financial investigation, proceeds of crime restraint and confiscation. It is also highlighted that the "tracing of Terrorist Financing is more an intelligence exercise than a legal procedure and insists that it should strengthen the international information exchange." 18 Other problems are related to administration of networked programs. For instance, banks may not report potentially suspicious activities or not report them in time because it could affect their funds flow. States may be lacking in political will to prosecute cases with acceptable evidence as unearthed by the network. This could restrain cooperation in true spirit; despite the presence of U.N. resolutions and conventions with the internal local laws and regulations. In fact global infrastructure system can assert any member state to take action in synchronizing domestic laws and its enforcement. But it is not binding; if the country is not willing to do so as in the case of FATF.

Criminals are proactive and take full advantage of complex international financial system. Today it is almost impossible to trace any form of organised criminal activity without first reaching its overseas proceeds, through multiple jurisdictions and financial accounts. Law enforcement agencies are gradually switching their attention from individual criminals to the financial gains from criminal activities. It is urgent requirement for legislation to combine forfeiture of proceeds of criminal activity with concrete array of prosecutorial and other channels to counter against organised transnational crime. These instruments should have computerised information systems, protection schemes of witnesses, monitoring systems, financial and business coordination and support, enhancing forensic expertise, acceptable asset-management/asset-sharing procedures under international agreements. Such types of acceptable methods should be controlled by strict observance of legal requirements and the principles of criminal procedure.

Money laundering and terrorist financing have serious socio-politico and economic consequences. Weak money laundering regime is the main cause of fragile financial system where reputational risk is high. This is not limited to country, but has broader impacts on global economy. Strong anti-financial crime and financing of terrorism regime is need of the hour. This is responsible for integral working of financial institutions with lower reputational risk. During the study, it was found various weak anti financial crime and financing of terrorism regime. This is an outcome of less competence, expertise, and non-adherence of local laws according to contemporary circumstances. Besides that, from psycho-social perspective human deviance in the form of rising

\footnotetext{
${ }^{17}$ World Bank, 2004

${ }^{18}$ Gilmore, W., \& Levi, M., Terrorist Finance, Money Laundering and the Rise and Rise of Mutual Evaluation: A New Paradi-gm for Crime Control? (Hague: European Journal of Law Reform, 2002), Vol. 4(2), 337-364.
} 
corruption also contributes in deteriorating regime's performance in country. Information collected, collated and interpreted in the light of set objectives. This helped the researcher to find out root causes and existing weakness at the regime's end, in countering financial crime and financing of terrorism. This also resulted in pervasiveness of such type of organised crimes in Pakistan.

In the light of this research, it is clear that there is a need to assess the actual participation of organised crime groups in the criminal markets in Pakistan. It demands to analyse and throw more light the modus operandi of organised criminal groups. This would lead to know, how organised criminal groups launder their ill-gotten money and systematically infiltrate in legitimate companies. Earlier this aspect was taken up by the researchers from law enforcement point of view. An innovative approach is needed to specify that how criminal organisations infiltrate their illegal proceeds and the drivers play a pivotal role in the decision-making of criminal groups; instead of solely relying on various elements of the offence of laundering. In this respect, major attention is needed to develop a knowledge base. This requires case studies, formation of database of reported cases where the legitimate businesses and companies are infiltrated with illicit funds in Pakistan.

\section{Conclusion}

The main object of this research work is to discuss types of organised crimes in general and in particular, criminological reviewed of methodologies and various impediments come in the way of countering financial crime and financing of terrorism in Pakistan. The review is further substantiated with various shortcomings found in financial crime and financing of terrorism regime; alongwith loopholes concluded during dissection of contemporary related statutes and regimes in Pakistan. The research would contribute in addressing serious organised crime issues with particular reference to money laundering and terrorist financing in the country.

\section{Recommendations}

Pakistan still has to do more in meeting international standards of AML and CFT, especially synchronizing local laws and provisions with FATF Recommendations. There is need of taking stringent reforms through organised crime legislation in line with international measures. There are limited entities in Pakistan, which are providing financial services (but not financial institutions in actual) as defined by FATF Recommendations. But these are not included in the AML/CFT mechanism, particularly Pakistan Postal Service (Pakistan Post Savings Bank) and the Central Directorate of National Savings (CDNS) which deals with national savings scheme borrowed from the general public. To bring these entities in the scope of AML/CFT, it requires amendment in AML Act. As a part of its financial sector reforms, Pakistan needs to be more stringent in its policies towards reforming remittance channels and to crack down on unregulated money changers and Hawala through the licensing of exchange companies. However, drastic measures were already introduced which marked decrease in the use of the Hawala system and an increase in the use of formal remittance channels. This has resulted in incerase of cross border remittances through financial channels and country 
reserves. The Anti-Terrorism Act should be amended so as to provide a mechanism for the freezing of assets of entities in compliance to UNSCR 1373.

Currently, FMU needs further investigative expertise in commensurate with changing typologies and technological advancements. Since NGOs have proved to be a serious channel of layering in money laundering. There is need of coordination among Social Welfare Ministry and FMU for information sharing. SECP and FBR can play a vital role in this regard. However, Ministry Social Welfare shares information on FT issues with Ministry of Interior.

The organised crimes, particularly money laundering alongwith recently terrorist financing activities by the organised criminal groups, are penetrating in social fabrics. It is recommended more legislative bodies promulgate stricter legislative measures with stringent law enforcement which may require some compromise on civil liberties. The current Protection of Pakistan Bill 2014 is recently adopted by the legislature of Pakistan is one of the precedent of making efforts to counter extra ordinary challenges in the extra ordinary terrorist activities in the country. The bill bestows more authority to enforcement agencies against the arrests, investigation and collection of evidence. The waging of 'war' against terrorists' networks in border area is also welcome action by Pakistan army under formal operation namely 'Zarb-e-Azab'. This operation is targeting terrorists and their sanctuaries in North Waziristan (Tribal belt at West Pakistan border). Such type of surgical action is also recommended against prevailing money laundering and corruption in the country. To the researcher; the tacit acceptance of corruption in the society is another rising organised criminal trend in the country; which needs more attention by the counter regime in Pakistan. If timely action is not taken; it would facilitate money laundering, terrorist financing with more organised crimes and at larger scale in the country. This would also distort social and moral values and vanning of respect for rule of law as a whole.

Since each country applies various structures, techniques and methods in combating organised crime. In some cases; these could be fundamentally different. The major channel could be effective in regulating their interaction at the national; regional and global level; is network among law enforcement agencies in investigating, apprehending, and prosecuting international criminals. It is call of the day; to establish mechanism of co-operation and communication and shared understanding of common goals throughout the world. Major assistance in tracing organised criminal groups is provided by cooperation in investigation between law enforcement agencies and special units. This allows exchange of essential information to neutralize the activities and movements of criminal groups. Enhanced cooperation may then create sufficient checks on organised crimes particularly money laundering, terrorist financing and terrorist organisations against their successful international operation. However, serious implementation is suggested for Customer Due Diligence at the institutions.

The country needs non-traditional anti-organised crime measures. This requires a community based engagement in countering money laundering and terrorist financing. This involves creating awareness among youth against criminal activities of organised criminal groups in the society. Through legal assurances, the private sector of the country 
should be engaged to minimize opportunities for organised criminal groups. So that they should not get an opportunity to launder their ill-gotten funds.

Pakistan has not been able to cope up with the global anti money laundering and terrorist financing regime's requirements. The future research requires reviewing of factors which restrain Pakistan from following global requirements in letter and spirit. So that anti organised crime regime in Pakistan with particular reference to countering money laundering and terrorist financing, could firm its footing against these serious rising challenges in the country.

\section{References}

Betti Stefano The European Union and the United Nations Convention Against Transnational Organised Crime: European Parliament Working Paper, Civil Liberties Series LIBE 116 EN (European Parliament 2001).

Buscaglia, Edgardo, Samuel, Gonzalez-Reiz, and Ratcliff, William (2005) Undermining the Foundations of Organised Crime and Public Sector Corruption: An Essay on Best International practises. Stanford: Hoover Institution on War

Cesoni, Maria Luisa "Mafia-Type Organizations: The Restoration of Rights as a Preventive Policy" in Viano Emilio C Viano Emilio C (ed) Global Organised Crime and International Security (Ashgate Aldershot 1999) 157- 171.

Duyne, P. C. van (1995) Organised Crime in Europe. New York: Nova Science Publishers

Fijnaut, C. \& Paoli, L. (2004) Organised Crime in Europe: Concepts, Patterns and Policies in the Eurropean Union and Beyond. Dodrecht: Springer

Gilmore, W., \& Levi, M., Terrorist Finance, Money Laundering and the Rise and Rise of Mutual Evaluation: A New Paradigm for Crime Control? (Hague: European Journal of Law Reform, 2002), Vol. 4(2), 337-364.

Gottschalk, Petter (2010) Policing Organised Crime: Intelligence Strategy Implementation. Boca Raton : CRC Press

Kelly, Robert J. (1978) Organised Crime: A Study in the Production of Knowledge by Law Enforcement Specialists. New York: The City University of New York

Layman M. D. \& Potter G. V. (2009) Organised Crime. Skopje: Magor

Obokata, Tom (2010) Transnational Organised Crime in International Law. Oxford: Hart Publishing

Patton, M. (1990). Qualitative evaluation and research methods (pp. 169-186). Beverly Hills, CA: Sage. 
Slaughter, Anne-Marie, A New World Order. (New Jersey: Princeton University Press, 2004)

Sutherland, Edwin H. (1937) The Professional Thief: By A Professional Thief. Chicago: The University of Chicago Press

Von Lampe Klaus "Organised Crime in Europe" in Reichel Philip (ed) Handbook of Transnational Crime and Justice (Sage Publications Thousand Oaks 2005) 403-424.

Wilke, Marie, Emerging Informal Network Structures in Global Governance. (Nordic Journal of International Law. Vol. 77, No. 4 (2008), 523.

Van Vliet, Gretchen L. A Partnership for Global Health: Expanding Curriculum and Research in Global Health (University of North Carolina: Chapel Hill, 2006), 10-11. 